\title{
PERSEPSI GURU TERHADAP PEMBELAJARAN MATEMATIKA BERBASIS LINGKUNGAN
}

\author{
Dian Nopitasari' ${ }^{1}$, Dadang Juandi² \\ 1 Universitas Muhammadiyah Tangerang, Jl.Perintis Kemerdekaan 1 No.33 Cikokol, Tangerang, Indonesia \\ 2 Universitas Pendidikan Indonesia, Jl. Dr. Setiabudhi No. 229 Bandung, Indonesia \\ Email: dian.nopitasari511@gmail.com
}

\begin{abstract}
Environmental-based mathematics learning is one way of learning mathematics that makes environmental issues a major medium in learning. Environmentally based mathematics learning raises examples of environmental problems in each teaching-learning activity, so students will also feel that math learning is not separated from their living environment. This research aims to describe teacher perceptions of environmentally-based mathematics learning. This type of research is survey research. The results showed that math teachers have a positive perception of environmentally-based learning.
\end{abstract}

Keywords: Mathematics teacher, learning based on environment, teacher perception

\section{ABSTRAK}

Pembelajaran matematika berbasis lingkungan adalah salah satu cara pembelajaran matematika yang menjadikan isu-isu lingkungan sebagai media utama dalam pembelajaran. Pembelajaran matematika berbasis lingkungan mengangkat contoh permasalahan yang berkaitan dengan lingkungan hidup pada setiap kegiatan belajar mengajar, sehingga siswa pun akan merasa bahwa pembelajaran matematika tidak terpisah jauh dengan lingkungan kehidupan mereka. Penelitian ini bertujuan untuk mendeskripsikan persepsi guru dalam pembelajaran matematika berbasis lingkungan. Jenis penelitian ini adalah penelitian survei. Hasil penelitian menunjukkan bahwa guru matematika memiliki persepsi positif terhadap pembelajaran berbasis lingkungan.

Kata kunci: Guru matematika, pembelajaran berbasis lingkungan, persepsi guru

Dikirim: 24 Februari 2020; Diterima: 25 Agustus 2020; Dipublikasikan: 30 September 2020

Cara sitasi: Nopitasari, D., \& Juandi, D. (2020). Persepsi guru terhadap pembelajaran matematika berbasis lingkungan. Teorema: Teori dan Riset Matematika, 5(2), 156-162. 


\section{PENDAHULUAN}

Kompleksitas masalah lingkungan harus diikuti oleh penyelesaian yang terintegrasi upaya di setiap sektor. Upaya untuk membuat orang sadar tentang lingkungan mereka harus dilakukan melalui pendidikan. Upaya ini disebut pendidikan lingkungan. Lingkungan pelaksana pendidikan secara optimal harus dilakukan tidak dengan sendirinya tetapi terintegrasi dengan semua bidang studi termasuk pendidikan formal matematika seperti yang diminta oleh banyak organisasi internasional. Pada dasarnya, dalam pendidikan matematika, guru menggunakan masalah kontekstual sebagai sarana untuk siswa untuk memahami matematika. Beberapa penelitian menyatakan bahwa matematika memiliki peluang menjadi salah satu bidang studi yang membahas tentang masalah sosial termasuk lingkungan (Habibi, 2014; Litner, 2016; Schwartz, 2010). Niat penyelenggaraan pendidikan lingkungan adalah untuk mengubah perilaku seseorang agar memiliki moral lingkungan yang baik (kesadaran, pengetahuan, sikap, keterampilan, dan partisipasi). Lingkungan moral inilah yang kemudian digunakan sebagai dasar kemampuan berpikir seseorang dalam menyikapi fenomena lingkungan yang terkait dengan masyarakat sosial. Dari sini kita dapat melihat garis tipis antara pendidikan dan pendidikan lingkungan, dimana keduanya dimaksudkan untuk mewujudkan kehidupan yang lebih baik bagi masyarakat (Gutierrez, 2013).

Berdasarkan lingkungan pendidikan matematika, kita dapat melihat dua manfaat seperti: (1) akan lebih mudah bagi siswa untuk memahami lingkungan karena mereka akan terbantu oleh perhitungan matematika; dan (2) melalui konteks lingkungan, siswa dapat mengembangkan kemungkinan matematika seperti: menganalisis, merepresentasikan, memodelkan, dan menafsirkan data (Dewi, 2015). Dari dua hal tersebut, siswa harus dapat mengubah perilaku mereka sebagai perintis perubahan di dunia sehingga mereka lebih kritis dan sensitif tentang fenomena sosial dan hal-hal lain. Pembelajaran matematika terintegrasi dapat meningkatkan kepedulian siswa dan juga bisa meningkatkan kemampuan berpikir kritis (Bacon, 2013; Bartell, 2011). Beberapa penelitian dan memberikan kesempatan untuk membuat matematika terintegrasi dengan masalah sosial dan masalah kontekstual. Pemberian masalah kontekstual kepada siswa dapat mengembangkan pemahaman dan kemampuan siswa dalam pembelajaran matematika (Bartell, 2011). Pendidikan matematika dan lingkungan memiliki beberapa kelebihan. Setidaknya ada dua keuntungan dari mengajar matematika dengan konteks lingkungan. Pertama, para siswa akan memahami keadaan mereka. Kedua, mereka dapat mengembangkan kompetensi matematika. Selain itu, kedua kompetensi tersebut dapat mengubah perilaku siswa sebagai pelopor perubahan masa depan yang lebih kritis terhadap fenomena sosial di sekitar mereka (Mayasari, 2019).

Masalah lingkungan adalah bagian besar dari keadilan sosial dan mempengaruhi individu serta komunitas diseluruh dunia. Penting bagi siswa untuk menyadari masalah lingkungan nasional dan global, memiliki pengetahuan untuk menganalisa pengaruhnya, dan pertimbangkan cara untuk memperbaikinya. Salah satu cara untuk melakukannya adalah melihat dan menganalisis masalah lingkungan melalui matematika, termasuk grafik, pengumpulan data, perhitungan numerik, statistik, dan banyak lagi (Mihailović et al., 2017).

Pembelajaran matematika sebagai bagian dari kurikulum sekolah dapat memberikan sumbangan besar dalam upaya pendidikan karakter bangsa. Penerapan nilai-nilai matematika yang sesuai dengan kaidah-kaidahnya dan diintegrasikan dengan realitas kehidupan sehari-hari seperti dikaitkan dengan isu lingkungan diharapkan mampu menjadikan siswa yang tidak hanya pandai matematika tetapi juga memiliki kepedulian terhadap lingkungannya (Hasanah, 2014). Sehingga, pembelajaran matematika akan mampu turut serta memberikan sumbangan positif dalam pengelolaan dan pelestarian lingkungan hidup. Karakter positif yang dibangun melalui pembelajaran matematika yang dikaitkan dengan isu lingkungan tersebut memerlukan kreativitas guru. Setiap interaksi belajar mengajar baik konsep ataupun contoh permasalahan di upayakan untuk dikaitkan dengan nilai-nilai yang berwawasan lingkungan. Lingkungan yang terjaga akan menghindarkan bencana dan dapat dimanfaatkan untuk meningkatkan kesejahteraan manusia yang mengelolanya.

Berdasarkan observasi yang pernah dilakukan oleh peneliti, dalam proses pembelajaran menunjukkan bahwa proses pembelajaran matematika masih monoton seperti siswa disuruh 
mencatat bahan pelajaran yang sudah ada dalam buku, misalnya saat guru sedang mengajar materi Matematika tentang menghitung luas lahan. Guru menjelaskan materi tersebut dan kemudian siswa disuruh merangkum isi materi yang ada di dalam buku tersebut. Dari segi pemanfaatan sumber daya yang ada di sekitar sekolah terutama untuk mata pelajaran Matematika, sering kali sarana proses belajar mengajar di kelas, laboratorium, perpustakaan, belum dimanfaatkan secara baik. Kelengkapan dan fasilitas belajar kurang memadai dengan alasan anggaran yang kurang memadai, diantara guru kurang terampil dalam menggunakan alat peraga Matematika, manajemen sekolah yang kaku, dan sebagainya.

Matematika merupakan salah satu mata pelajaran wajib untuk sekolah jenjang dasar dan menengah. Matematika merupakan bidang kajian yang netral tanpa pengaruh politik di dalamnya sehingga sangat memungkinkan untuk memilih matematika sebagai sarana untuk mengembangkan pendidikan moral (Gutierrez, 2013; Tutak et al., 2011; Bacon, 2013). Tujuan umum diberikannya matematika pada jenjang pendidikan dasar dan menengah meliputi dua hal, yaitu: (1) menyiapkan siswa agar sanggup menghadapi perubahan keadaan di dalam kehidupan dan di dunia yang selalu berkembang, melalui latihan bertindak atas dasar pemikiran secara logis, rasional, kritis, cermat, jujur, efektif dan efisien; dan (2) menyiapkan siswa agar dapat menggunakan matematika dan pola pikir matematika dalam kehidupan sehari-hari dan dalam mempelajari berbagai ilmu pengetahuan. Dari tujuan umum tersebut dapat dilihat bahwa matematika sekolah memegang peranan penting. Siswa memerlukan matematika untuk memenuhi kebutuhan praktis dan pemecahan masalah dalam kehidupan sehari-hari. Selain itu agar siswa mampu mengikuti pelajaran matematika lebih lanjut, untuk membantu memahami bidang studi lain, agar siswa dapat berpikir logis, kritis dan praktis serta bersikap positif dan berjiwa kreatif (Habibi, 2014).

Teori pembelajaran yang menyatakan bahwa pembelajaran banyak terjadi di lingkungan sosial. Dari perspektif teoritis ini, fungsi manusia merupakan hasil dari proses interaksi dinamis antara pribadi, perilaku, dan pengaruh lingkungan (Zakiah \& Fajriadi, 2020). Pembelajaran matematika berbasis lingkungan adalah salah satu cara pembelajaran matematika yang menjadikan isu-isu lingkungan sebagai media utama dalam pembelajaran. Pembelajaran matematika berbasis lingkungan mengangkat contoh permasalahan yang berkaitan dengan lingkungan hidup pada setiap kegiatan belajar mengajar, sehingga siswa pun akan merasa bahwa pembelajaran matematika tidak terpisah jauh dengan lingkungan kehidupan mereka (Hidayati, 2008). Dengan demikian pembelajaran matematika berbasis lingkungan yang dimaksud dalam penelitian ini adalah pembelajaran matematika yang mengintegrasikan isu-isu lingkungan hidup sebagai media dalam pembelajaran dengan menggunakan pengalaman dan lingkungan peserta didik.

\section{METODE PENELITIAN}

Jenis penelitian yang digunakan dalam penelitian ini adalah survei dimana fenomena yang akan diteliti adalah kejadian yang telah berlalu atau sedang berlangsung, dalam konteks ini adalah proses pembelajaran. Sugiyono (2013) mengungkapkan bahwa metode penelitian survei digunakan untuk mendapatkan data dari tempat tertentu yang alamiah (bukan buatan), tetapi peneliti melakukan perlakuan dalam pengumpulan data.

Sugiyono (2013) mengungkapkan bahwa metode penelitian survei digunakan untuk mendapatkan data dari tempat tertentu yang alamiah (bukan buatan), tetapi peneliti melakukan perlakuan dalam pengumpulan data, misalnya dengan mengedarkan kuesioner, wawancara terstruktur dan sebagainya (perlakuan tidak seperti dalam penelitian eksperimen). Selanjutnya, Arikunto (2010) menjelaskan bahwa dalam penelitian deskriptif, peneliti tidak memberikan perlakuan khusus kepada obyek yang diteliti namun memaparkan atau menggambarkan keadaan, kondisi atau peristiwa yang terjadi secara apa adanya.

Desain yang digunakan dalam penelitian ini adalah survey descriptive design. Sebagaimana yang dikemukakan oleh Sugiyono (2013) berbagai langkah yang harus dilaksanakan dalam penelitian ini, antara lain: (1) memilih dan merumuskan masalah. Masalah yang akan diteliti yaitu bagaimana persepsi guru dan siswa terhadap pembelajaran matematika berbasis lingkungan; 
(2) menentukan tujuan dari penelitian yang akan menjawab rumusan masalah; (3) memberikan batasan-batasan penelitian dan menentukan sampel; (4) menyusun tinjauan pustaka; (5) menyusun instrumen pengumpulan data; dan (6) melakukan pengumpulan data, teknik pengumpulan data yang digunakan adalah kuesioner dan wawancara terstruktur.

Dalam pengumpulan data pada penelitian ini, teknik yang digunakan adalah sebagai berikut: (1) penyusunan instrumen penelitian. Tahap ini dilakukan sebelum melaksanakan penelitian. Instrumen yang disusun terdiri dari angket persepsi siswa pada aspek hasil belajar dan wawancara terstruktur; (2) pengumpulan data; 3) analisis data. Analisis data dilakukan setelah semua data yang dibutuhkan telah terkumpul; dan (4) kesimpulan. Setelah data dianalisis, hasil yang diperoleh diambil kesimpulannya dengan melihat apakah tujuan dari penelitian sudah tercapai atau belum.

\section{HASIL DAN PEMBAHASAN}

Pembelajaran Matematika berbasis lingkungan adalah pendidikan lingkungan hidup yang diintegrasikan dalam pembelajaran matematika. Konsep lingkungan akan mudah diterapkan dalam proses belajar mengajar jika siswa diajak untuk mengaitkan kejadian alam sekitarnya dengan pembelajaran yang akan dilakukan. Pembelajaran matematika berbasis lingkungan merupakan pendidikan lingkungan hidup yang diintegrasikan dalam pembelajaran matematika. Proses integrasi antara pembelajaran matematika dan pendidikan lingkungan hidup dapat dilakukan dalam kegiatan atau langkah-langkah dalam proses pembelajaran seperti pada kegiatan pendahuluan, kegiatan inti, maupun kegiatan penutup. Integrasi matematika berbasis lingkungan dalam pembelajaran dapat dilakukan tergantung pada model pembelajaran yang akan digunakan serta materi pembelajaran yang akan dibahas. Model pembelajaran merupakan suatu gambaran prosedur yang sistematis mengenai proses pembelajaran yang ditentukan oleh pendidik untuk mengorganisasikan pengalaman belajar peserta didik untuk mencapai tujuan belajar tertentu. Model pembelajaran berfungsi sebagai pedoman dalam merencanakan dan melaksanakan proses belajar mengajar. Penggunaan model pembelajaran tergantung pada materi atau konsep matematis yang akan disampaikan. Selama materi atau konsep matematis yang akan dibahas dapat dikaitkan dengan pendidikan lingkungan hidup dan konsep matematis dapat dipahami serta kondisi dan situasi peserta didik memungkinkan maka pendidik dapat menggunakan model yang sesuai dengan materi yang akan disampaikan.

Pembelajaran matematika adalah proses pemberian pengalaman belajar kepada siswa melalui serangkaian kegiatan yang terencana sehingga siswa memperoleh kompetensi tentang bahan matematika yang dipelajari. Suatu proses pembelajaran akan dikatakan berhasil apabila diawali dengan perencanaan yang sangat matang. Begitu pula dengan pembelajaran matematika akan dapat berjalan efektif dan berhasil apabila dilakukan melalui persiapan dan perencanaan yang matang.

Seorang pendidik perlu terampil dalam merencanakan suatu proses pembelajaran. Karena dalam proses pembelajaran memerlukan acuan atau landasan yang jelas agar perilaku setiap individu yang melakukan aktivitas pembelajaran akan terkendali serta terarah ke arah pencapaian tujuan, baik tujuan pembelajaran secara khusus, maupun tujuan pembelajaran secara umum. Dapat dipahami bahwa perencanaan pembelajaran memiliki peran penting dalam meningkatkan mutu pembelajaran.

Data persepsi guru terhadap pembelajaran matematika berbasis lingkungan didapatkan melalui proses wawancara terhadap 3 guru IPA dari 3 sekolah yang berbeda. Adapun indikator untuk mendapatkan persepsi guru terhadap pembelajaran matematika berbasis lingkungan yaitu persepsi tentang idealnya sebuah pembelajaran matematika, persepsi tentang pembelajaran berbasis lingkungan saat ini, persepsi tentang kendala dalam menerapkan pembelajaran berbasis lingkungan.

Guru matematika memiliki persepsi positif terhadap pembelajaran berbasis lingkungan. Guru perlu memiliki kemampuan untuk melakukan kreatifitas dan pengembangan pengetahuan yang 
memadai tentang fenomena lingkungan sehingga dapat melakukan pengembangan media dalam menggunakan bahan-bahan dan lingkungan. Perlu adanya pengembangan mengenai perangkat pembelajaran matematika khususnya pada RPP dan LKS yang berlandaskan masalah kontekstual. Hal ini dikarenakan agar siswa dapat lebih termotivasi dengan pembelajaran matematika yang sesuai dengan lingkungan kehidupan siswa. Salah satu bentuk optimalisasi masalah kontekstual tersebut adalah pembelajaran matematika yang diintegrasikan dalam pendidikan lingkungan hidup.

Kendala dalam pembelajaran matematika berbasis lingkungan memang dialami guru maupun siswa. Kendala yang ditemukan dalam penelitian ini adalah kendala waktu musim hujan yang tidak memungkinkan pembelajaran dilakukan di luar kelas, kendala sarana belajar yang terbatas dan kendala guru kesulitan melakukan koordinasi siswa, karena antusias siswa yang sangat besar. Kesulitan tersebut berasal dari reaksi siswa yang sangat senang ketika diajak belajar di luar kelas. Suasana senang tersebut diekspresikan siswa dengan berbagai macam cara. Kondisi tersebut menyebabkan suasana kelas menjadi ramai.

Selain itu berdasarkan angket jawaban terbuka, diperoleh respon siswa sebagai berikut: (1) pada umumnya siswa merasa senang dengan model pembelajaran berbasis lingkungan; (2) pada umumnya siswa memberikan kesan bahwa pembelajaran berbasis lingkungan akan cukup menarik karena siswa dapat belajar matematika di luar kelas dan dapat digunakan sebagai metode alternatif agar pembelajaran tidak monoton dan membosankan, namun ada juga walaupun sedikit siswa yang menyatakan bahwa metode yang digunakan kurang menarik; (3) sebagian besar siswa menyarankan agar dalam penggunaan model pembelajaran ini materi dijelaskan dengan lebih detail dan sebagian siswa juga menengeluhkan jam pelajaran matematika yang ada di akhir sehingga siswa sudah kurang konsentrasi mengikuti kegiatan pembelajaran, mereka menginginkan jam pelajaran matematika dipindah di pagi hari atau di jam-jam pertengahan; dan (4) terkait dengan sikap ramah lingkungan dalam arti kepedulian terhadap lingkungan hidup, sebagian besar siswa menyatakan bahwa dengan mengaitkan materi matematika dengan kehidupan sehari-hari siswa khususnya lingkungan hidup menjadikan mereka merasa semakin memiliki sikap peduli dengan lingkungannya dan semakin tahu bahwa ternyata matematika begita dekat dengan kehidupan sehari-hari para siswa, tidak sekedar konsep abstrak yang sulit dipelajari.

Guru matematika menyatakan bahwa keterbatasan dalam penerapan pembelajaran berbasis lingkungan adalah kendala waktu musim hujan yang tidak memungkinkan pembelajaran dilakukan di luar kelas, kendala sarana belajar yang terbatas dan kendala guru kesulitan melakukan koordinasi siswa, karena antusias siswa yang sangat besar. Kesulitan tersebut berasal dari reaksi siswa yang sangat senang ketika diajak belajar di luar kelas. Suasana senang tersebut diekspresikan siswa dengan berbagai macam cara. Kondisi tersebut menyebabkan suasana kelas menjadi ramai. Berdasarkan kejadian tersebut, dapat dikaji dari penelitian terdahulu yang pernah dilakukan oleh Potter (2008), "Sociocultural diversity and literacy teaching in complex times: the challenge for early childhood educators, childhood education". Dalam penelitian tersebut dikemukakan bahwa selama beberapa tahun, guru sangat dipengaruhi oleh kemauan untuk berkembang dalam melakukan merespon untuk bermacam-macam kebutuhan dari setiap individu anak. Artinya kendala atas reaksi berlebihan anak dapat disikapi dengan menggali potensi yang dapat dikembangkan dari reaksi siswa. Misalnya dengan memberikan tugas untuk menyusun ringkasan setelah kegiatan belajar selesai.

Temuan kendala tersebut menginspirasikan guru untuk tetap melakukan inovasi kepada guru. Hal ini sesuai dengan penelitian terdahulu yang pernah dilakukan oleh Sessoms (2008) Interactive instruction: creating interactive learning environments through tomorrow's teachers". Inovasi memberikan kemampuan baru yang dapat mengubah proses belajar mengajar. Transformasi proses belajar mengajar akan berarti bahwa guru menciptakan perbedaan lingkungan belajar fundamental yang mempromosikan interaktivitas. Sekolah memiliki kesempatan untuk membuat "alam digital" dengan menanamkan konsep lingkungan belajar interaktif dalam program tradisional. Ketika guru siap dengan sadar mengintegrasikan teknologi untuk menciptakan lingkungan belajar 
interaktif, akan menjadi bagian dari semua yang mereka lakukan di dalam kelas. Berpikir tentang siswa sebagai produsen menyiratkan bahwa siswa secara aktif berpartisipasi dalam proses belajar dan ini terjadi dalam sebuah kelas interaktif yang menggunakan alat interaktif. Produser juga berarti bahwa siswa beroperasi pada keterampilan berpikir tingkat tinggi saat mereka menganalisis, mensintesis, dan pengetahuan hadir untuk teman sebaya secara lokal maupun global. Guru yang menciptakan lingkungan belajar interaktif harus dilengkapi dengan baik keterampilan teknis dan pedagogi terintegrasi dengan teknologi.

\section{KESIMPULAN}

Berdasarkan paparan hasil penelitian yang telah dilaksanakan, dapat disimpulkan bahwa secara umum, guru matematika memiliki persepsi positif terhadap pembelajaran berbasis lingkungan. Guru perlu memiliki kemampuan untuk melakukan kreatifitas dan pengembangan pengetahuan yang memadai tentang fenomena lingkungan sehingga dapat melakukan pengembangan media dalam menggunakan bahan-bahan dan lingkungan. Terlepas dari keterbatasan-keterbatasan yang ada guru berminat untuk menerapkan pembelajaran tersebut. Data dalam penelitian ini masih dapat dikembangkan dan digali lebih mendalam. Penelitian tentang persepsi guru dan siswa terhadap suatu pembelajaran berbasis lingkungan dapat digunakan untuk membangun ide program-program pengembangan profesionalisme guru.

\section{REKOMENDASI}

Dengan memperhatikan hasil penelitian dan kesimpulan yang telah dikemukakan maka peneliti menyarankan agar dalam mengembangkan kemampuan kognitif maupun afektif perlu untuk menerapkan pembelajaran berbasis lingkungan.

\section{DAFTAR PUSTAKA}

Arikunto. (2010). Prosedur penelitian: Suatu pendekatan praktek. Jakarta: Rineka Cipta.

Bacon, C. (2013), Implementing social justice in math during the standards based era. Implementing Social Justice. Rising Tide, 5, 1-22.

Bartell, T. G. (2011). Caring, race, culture, and power: A research synthesis toward supporting mathematics teachers in caring with awareness. Journal of Urban Mathematics Education, $4(1), 50-74$.

Dewi, D. A. (2015). Matematika hijau sebagai salah satu upaya pendidikan karakter berwawasan lingkungan. Math Didactic: Jurnal Pendidikan Matematika, 1(1), 33-38.

Gutierrez, R. (2013). The sociopolitical turn in mathematics education. Journal for Research in Mathematics Education, 44(1), 37-68.

Habibi, M. (2014). Environment education in mathematics classroom: as an effort to develop the critical thinking skills and for environment sustainability concering. Proceeding of International Conference on Research, Implementation and Education of Mathematics and Sciences, Yogyakarta State University.

Hasanah, S.I. (2014). Sumber belajar matematika dari lingkungan alam sekitar berbasis pondok pesantren. INTERAKSI, 9(1), 28-31.

Hidayati, K., Arliani, E., Retnawati, H., \& Isnaeni, I. (2008). Implementasi pembelajaran matematika berwawasan lingkungan dengan pendekatan kooperatif guna mengembangkan sikap ramah 
lingkungan dan meningkatkan hasil belajar siswa. Pythagoras: Jurnal Matematika dan Pendidikan Matematika, 4(1), 33-46.

Litner, M. (2016). The role of environmental education in the ontario elementary math curriculum. Ontario Institute for Studies in Education of the University of Toronto.

Mayasari, D., Natsir, I., \& Munfarikhatin, A. (2019). Improving capability of student based on green mathematics through nation character education for caring the environment. IOP Conf. Series: Earth and Environmental Science, 343 012215, 1-6.

Mihailović, D. T., Balaž, I., \& Kapor, D. (2017). Interrelations between mathematics and environmental sciences. Time and Methods in Environmental Interfaces Modelling Personal Insights, 253-263. doi:10.1016/b978-0-444- 63918-9.00019-3.

Potter, G. (2008). Sociocultural diversity and literacy teaching in complex times: the challenge for early childhood educators. Childhood Education; Winter 2007/2008; 84, 2; Academic Research Library. pg. 64.

Schwartz, R. H. (2010). Relating mathematics to environment eucation. The Journal of Environment Education. College of Staten Island, USA.

Sessoms, D. (2008). Interactive instruction: Creating interactive learning environments through tomorrow's teachers. International Journal of Technology in Teaching and Learning, 4, 8696.

Sugiyono. (2013). Metode penelitian pendidikan (Pendekatan kuantitatif, kualitatif, dan R\&D). Bandung: Alfabeta.

Tutak, F. A., Bondy, E., \& Adams, T. L. (2011). Critical pedagogy for critical mathematics education. International Journal of Mathematical Education in Science and Technology, 42(1), 65-74.

Zakiah, N. E., \& Fajriadi, D. (2020). Self regulated learning for social cognitive perspective in mathematics lessons. J. Phys.: Conf. Ser. 1613 012049. doi:10.1088/17426596/1613/1/012049. 